\title{
Geochemical evolution of the New England lamprophyre suite: a hotspot signature preserved in the continental crust?
}

\author{
Smith, S.C. and Thinger, P.D. \\ Department of Geology and Geophysics, Yale University, New Haven, CT, USA
}

Hotspots provide a means of investigating the physical and chemical evolution of the Earth's interior. Although we have successfully addressed many of the major questions concerning the deep mantle by studies of ocean island basalts, these investigations are limited by both inaccessibility to the full trace of magmatism on the ocean floor and the disappearance of the record of this magmatism by subduction after several hundred million years. Identification of uncontaminated fossil hotspot traces on the continents may allow us to study deep mantle samples that span the convective history of the Earth. Volatile-rich magmas, erupted quickly through the crust, may provide the best opportunity to sample primitive, uncontaminated deep mantle compositions. The lamprophyre dikes of the New England - Quebec igneous province, continuous in both time and space with the New England Seamounts, provide an ideal location in which to investigate the possibility that mafic alkaline volcanism represents the surface expression of the passage of a hotspot beneath continental crust. Lamprophyres are found on every continent and have erupted at least since the late Archean. Contrary to common opinion, they are not rare, volumetrically insignificant, or hopelessly altered.

We have analyzed samples from over 40 lamprophyre dike localities collected from Vermont, New Hampshire and southern Maine. Whole rock major and trace element analyses were performed on the full suite of these samples. $\mathrm{SiO}_{2}$ values range from 38 to $55 \mathrm{wt} \%, \mathrm{Mg}^{\# \text { 's }}$ range from 67 to 25 , the average $\mathrm{Na}_{2} \mathrm{O} / \mathrm{K}_{2} \mathrm{O}$ ratio is 2 , and the average LOI value is $4.5 \mathrm{wt} \%$. Trace element spidergrams match closely those of the New England Seamounts (Taras and Hart, 1987), as well as an average OIB compilation by Sun and McDonough (1989); LREE enrichments are observed in all samples, with average $L a$ values reaching $\sim 300 \mathrm{x}$ chondritic (Smith and Ihinger, in prep.). Twenty-eight samples were selected for a detailed investigation of the concentration and stable isotopic composition of $\mathrm{H}_{2} \mathrm{O}$ and $\mathrm{CO}_{2}$ in the whole rocks and in mineral separates (Smith and Ihinger, 1997). The concentration of $\mathrm{CO}_{2}$ ranges from 6.3 to $0.2 \mathrm{wt} \%$, and the carbon isotopic composition from $-4 \%$ to $-24 \%$. These data define a distinct degassing trend, modeled most closely by open system degassing with a $\Delta_{\text {vapor-melt }}$ of $+2 \%$. The concentration of $\mathrm{H}_{2} \mathrm{O}$ ranges from 3.8 to $0.6 \mathrm{wt} \%$, and the $\delta \mathrm{D}$ from $-51 \%$ to $-108 \%$. Based on these whole rock results and careful petrographic study, representative thin sections were prepared from 12 locations for microprobe analyses of mafic silicate phenocrysts, including pyroxenes, amphiboles, and biotites. These measurements provide constraints on the generation, emplacement and evolution of the host magmas.

\section{Pyroxenes}

In the New England lamprophyre suite, clinopyroxene appears to be the main fractionating phase. These pyroxenes are dominantly salite and titanaugite, plotting almost on the diopside-hedenbergite join, which is typical of pyroxenes crystallizing from strongly silica-undersaturated magmas. On a regional scale, the range in the composition of pyroxenes throughout our sample suite is marked by decreasing $\mathrm{Mg}$, $\mathrm{Si}$ and $\mathrm{Cr}$, with a concomitant increase in $\mathrm{Fe}$, Ti and $\mathrm{Al}$. The same trends are reflected in multiple analyses of phenocrysts from individual lamprophyre dikes, as well as in core to rim variations within single phenocrysts. Pyroxenes in lamprophyres are generally enriched in $\mathrm{Ti}$, in this study reaching values of $5.6 \mathrm{wt} \%$, with the enrichment being distinguished in thin section by a pale lilac to brownish color. There is an excellent correlation between octahedral Ti and Al(iv), suggesting $\mathrm{Ti}$ is entering these pyroxenes to charge balance the Al(iv), required by the silica undersaturated nature 
of these magmas (Kushiro, 1960). This is supported by the good correlation between Al(iv) in the pyroxenes and $\mathrm{SiO}_{2}$ undersaturation of the whole rocks. This compositional influence may be enhanced by the effect of increasing incorporation of Ti with decreasing pressure (Thompson, 1974). A substantial number of our analyses have $\mathrm{Al}(\mathrm{vi}) / \mathrm{Al}(\mathrm{iv})$ indicative of higher pressures of crystallization (Aoki and Kushiro, 1968). Cr is preferentially partitioned into early-crystallizing pyroxenes; some of the large, early-formed phenocrysts have up to $1.2 \mathrm{wt} \% \mathrm{Cr}_{2} \mathrm{O}_{3}$ in cores. These $\mathrm{Cr}$-rich cores also have the highest $\mathrm{Mg}^{\# \prime}$ s and the highest $\mathrm{Al}(\mathrm{vi})$. Complex oscillatory zoning reflects abrupt changes in the host melt environment during growth. Some crystals contain "evolved" green cores. They are generally enriched in $\mathrm{Na}$ and $\mathrm{Fe}^{3+}$ or sometimes in $\mathrm{Fe}^{3+}$ and $\mathrm{Al}$. They are often anhedral, reflecting resorption, and sometimes show zoning, also indicative of earlier changes in pressure, temperature, and/or melt composition during growth (Bedard, 1988a). Explanations for their origin include derivation from a high-pressure differentiation trend, from entrainment of external xenocrysts or xenocrysts crystallized from a previous pulse of more evolved magma, or derivation from extremely low degree partial melts at high pressures. Consistent with their occurrence in other mafic alkaline rocks, these green cores are common but not numerous. The vast majority of pyroxene phenocrysts in these rocks have the more magnesian compositions described above. With the dominant trend from core to rim of decreasing $\mathrm{Mg}^{\#}, \mathrm{Si}$ and $\mathrm{Cr}$, and increasing $\mathrm{Ti}$ and $\mathrm{Al}$, fractionation of these pyroxenes could reduce the $\mathrm{SiO}_{2}$ content and $\mathrm{Mg}^{\#}$ and increase the alkali content of the residual liquids. We note that concomitant crystallization of olivine, oxide or kaersutite would counteract the trend towards silica undersaturation produced by dominant clinopyroxene fractionation.

\section{Amphiboles}

In the New England lamprophyre suite, the ranges in amphibole compositions extend from kaersutite and hastingsite through to hastingsitic and edenitic hornblendes. Two distinct trends are evident in these phenocrysts. Ti-rich kaersutite is the dominant amphibole in both trends, and is generally distinguished by high $\mathrm{Fe}^{3+} / \mathrm{Fe}^{2+}$, high $\mathrm{F}$ contents (up to $0.8 \mathrm{wt} \%$ ), and low silica contents. As in the pyroxenes, the same relationship is evident between $\mathrm{Al}(\mathrm{iv})$ and $\mathrm{Ti}$, again as a result of the silicaundersaturated nature of the magmas. For dikes with higher whole rock $\mathrm{Mg}^{\# \text { 's }}$ and lower $\mathrm{SiO}_{2}$ contents, textures in thin section generally indicate late crystallization of amphiboles, with phenocrysts frequently forming smaller equigranular crystals distributed throughout the groundmass. These groundmass amphiboles show a very restricted range in composition, showing small increases in $\mathrm{SiO}_{2}$ with decreasing $\mathrm{Mg}^{\#}$. In dikes with lower whole rock $\mathrm{Mg}^{\# \prime}$ s and higher $\mathrm{SiO}_{2}$ contents, the modal percentage of pyroxene decreases, and amphibole becomes a more dominant phenocryst phase. These amphiboles display pronounced $\mathrm{SiO}_{2}$ decreases with decreasing $\mathrm{Mg}^{\#}$. The zoning in these amphiboles lacks the multiple reversals and sudden changes that are evident in the zoning of the larger pyroxene phenocrysts. Extreme $\mathrm{Mg}$ depletions and Fe enrichments are found on the rims of a few amphibole phenocrysts directly adjacent to heavily serpentinized olivine grains. These are likely the result of interaction with the serpentinizing reaction between olivine and the autometasomatic fluids, which build up in the late stages of cooling. Amphibole compositions vary more markedly between separate dike localities, with some being more silica-rich, and $\mathrm{Al}$ and $\mathrm{Ti}$ poor, and each lamprophyre defining its own restricted range in amphibole $\mathrm{Mg}^{\#}$. Large amphibole phenocrysts, on the order of several centimeters in length, with uniform compositions, have been reported from a variety of alkaline provinces, and are present in a number of the samples with higher $\mathrm{Mg}^{\# \text { 's }}$ from this study. They are titanian pargasites to magnesio-hastingsites, and differ from the smaller phenocrysts in having higher contents of $\mathrm{Mg}$ and $\mathrm{Al}$ and lower contents of $\mathrm{Ti}$. They have been interpreted as cognate due to coherent $\mathrm{Mg}^{\# \text { ' }}$ s between megacryst and enveloping whole rock, and are thought to have crystallized from the same magma source at depth (Bedard, 1988b). 


\section{Biotites}

Biotites are rare in comparison to amphibole in this lamprophyre suite. This is likely a result of the predominance of $\mathrm{Na}_{2} \mathrm{O}$ over $\mathrm{K}_{2} \mathrm{O}$ in these rocks and the shallower depth of generation compared to the ultrapotassic rocks such as lamproites and kimberlites. When present, the biotites appear to be late groundmass grains, with compositions that plot near the center of the phlogopite-annite end-members, indicative of the more Fe-rich conditions prevailing during the late stages of crystallization. Again they show the Al(iv) - Ti covariation typical of all the ferromagnesian silicates in these rocks. They show significant enrichment in $\mathrm{F}$ (up to $2.0 \mathrm{wt} \%$ ) similar to the amphiboles, and some have high contents $\mathrm{Ba}$ (up to $3.5 \mathrm{wt} \% \mathrm{BaO}$ ).

Knowledge of the compositional variations in the mafic silicates of the New England lamprophyre suite provides constraints on the processes occurring during the passage of these magmas through the crust. The presence and composition of cognate megacrysts, magnesian phenocryst cores with elevated $\mathrm{Al}(\mathrm{vi}) / \mathrm{Al}(\mathrm{iv})$, and "evolved" green cores mantled by more magnesian material, is suggestive of fractionation at depth, perhaps at the base of the crust. Compositions of pyroxene rims and hydrous phases point to an episode of shallower residence, consistent with the numerous distinct pulses of magma seen in single dikes. This is compatible with the existence of two populations of dikes delineated by stable isotopic compositions and concentrations of primary $\mathrm{CO}_{2}+\mathrm{H}_{2} \mathrm{O}$. One population is defined by isotopic compositions and elevated volatile contents suggestive of dissolution at high pressures, and precluding extensive degassing at shallower levels. The other population is marked by isotopic compositions and lower volatile contents that indicate substantial degassing. The similarity of absolute and relative trace element concentrations to those of the New England Seamounts suggests limited interaction of the lamprophyric magmas with the continental crust during their passage to the surface. Analyses of radiogenic and oxygen isotopes from some of the more evolved syenite and granite intrusions, to which the New England lamprophyres are generally thought to be genetically related, indicate little crustal contamination (Foland et al., 1985, 1988). Future studies focusing on radiogenic and oxygen isotopes in the silicates of the mafic lamprophyres will further constrain the amount of crustal assimilation. Clearly these magmas have experienced a very complex history. However, detailed investigations of variations in phenocryst compositions will help to unravel lamprophyre evolution, and point to the original character of the primary magmas and their potential relationship to hotspots.

Aoki, K., and Kushiro, I., 1968, Some clinopyroxenes from ultramafic inclusions in Dreiser Weiher, Eifel: Cont. Min. Pet., 18, p. 326-337. Bedard, J.H. et al., 1988a, Petrology and pyroxene chemistry of Monteregian dykes: the origin of concentric zoning and green cores in clinopyroxenes from alkali basalts and lamprophyres: Can. J. Earth Sci., 25, p. 2041-2058.

Bedard, J.H., 1988b, Comparative amphibole chemistry of the Monteregian and White Mountain alkaline suites, and the origin of amphibole megacrysts in alkali basalts and lamprophyres: Min. Mag., 52, p. 91-103.

Foland, K.A. et al., 1985, Petrogenesis of the magmatic complex at Mount Ascutney, Vermont, USA: I. Assimilation of crust by mafic magmas based on $\mathrm{Sr}$ and $\mathrm{O}$ isotopic and major element relationships: Contrib. Mineral. Petrol., 90, p. 331-345.

Foland, K.A. et al., 1988, Nd and Sr isotopic signatures of Mesozoic plutons in northeastern North America: Geology, 16, p. 684-687.

Kushiro, I., 1960, Si-Al relation in clinopyroxenes from igneous rocks: Am. J. Sci., 258, p. 548-554.

Smith, S.C. and Thinger, P.D., 1997, Volatile evolution in mafic alkaline rocks: A stable isotopic study of the New England Lamprophyre suite: EOS Trans. AGU, 78(46), Fall Meeting Suppl., p. F813.

Smith, S.C. and Thinger, P.D., 1998, Geochemical evolution of the New England lamprophyre suite: a hotspot signature preserved in the continental crust?, in prep.

Sun, S. -s. and McDonough, W.F., 1989, Chemical and isotopic systematics of oceanic basalts: implications for mantle composition and processes, From Saunders, A.D. and Norry, M.J.(eds.), 1989, Magmatism in the Ocean Basins, Geol. Soc. Spec. Pub. No. 42, p. 313-345. Taras, B.D. and Hart, S.R., 1987, Geochemical evolution of the New England seamount chain; isotopic and trace element constraints: Chem. Geol., 64, p. 35-54.

Thompson, R.H., 1974, Some high-pressure pyroxenes: Min. Mag., 39, p. 768-787. 